\title{
ÜMINIS KALKULINIS CHOLECISTITAS: ETIOLOGIJA, RIZIKOS VEIKSNIAI, KLINIKINIAI SIMPTOMAI IR DIAGNOSTIKA
}

\author{
Mantas Balčytis \\ Vilniaus universiteto Medicinos fakultetas
}

Raktažodžiai: cholecistitas, ūminis cholecistitas, kalkulinis cholecistitas, tulžies pūslès ligos, Tokijo gairès.

\section{Santrauka}

Lietuvoje atliekama 7000 cholecistektomijų per metus - tai trečia pagal dažnumą operacija šalyje. Tyrimo tikslas - įvertinti, susisteminti ir išanalizuoti mokslinèje literatūroje pateikiamus duomenis apie ūminį kalkulinį cholecistitą, etiologiją, reikšmingus rizikos veiksnius, galinčius turetti įtakos šios patologijos vystymuisi, ligos klinikinius simptomus bei diagnostikos ypatumus. Tyrimo metodas - sisteminè mokslinès literatūros apžvalga ir analizè. Duomenų buvo ieškoma Google Scholar, UpToDate, Cochrane ir Medline (PubMed) duomenų bazèse. Visateksčiai straipsniai atrinkti, jei jų pavadinimas, santrauka ar reikšminiai žodžiai nurodè, kad tyrimas tinkamas įtraukti ị šią apžvalgą. Atrinkti, išanalizuoti ir apibendrinti 6 viso teksto straipsniai. Tyrimo rezultatai parodè, kad akmenys tulžies pūslèje randami iki 95 proc. ligonių, sergančių ūminiu cholecistitu. Viena dažniausių tulžies pūslès akmenligès komplikacijų yra ūminis tulžies pūslès uždegimas. Moterys serga dažniau, ypač iki 50 metų. Dažniausiai pacientai skundžiasi skausmu po dešiniuoju šonkaulių lanku, pykinimu, vẻmimu. Ūminio cholecistito diagnostikai išsivysčiusiose šalyse taikomi Tokijo gairèse pateikti kriterijai.

Išvados. Dažniausiai ūminị cholecistitą sukelia tulžies latakuose įstrigęs akmuo. Būdingi simptomai: pykinimas, vėmimas, skausmas po dešiniuoju šonkaulių lanku. Ūminio cholecistito diagnostika remiasi Tokijo gairemis.

\section{İvadas}

Viena dažniausių tulžies pūslès akmenligės komplikacijų yra ūminis tulžies pūslès uždegimas. Lietuvoje atliekama 7000 cholecistektomijų per metus - tai trečia pagal dažnumą operacija Lietuvoje. Moterys iki 50 metų ūminiu cholecistitu serga 3 kartus dažniau negu vyrai, o po 50 metų - 1,5 karto dažniau, negu vyrai. 95 procentais atvejų sergantiesiems ūminiu cholecistitu randami akmenys tulžies pūslèje [1]. Dažniausiai ūminis cholecistitas prasideda tulžies akmenims užkimšus tulžies latakus, tik apie 10 proc. atvejų tulžies latakų obstrukcijos akmenimis nerandama [2]. Pacientai skundžiasi pykinimu, vėmimu, skausmu po dešiniuoju šonkaulių lanku, o skausmas dažniausiai suintensyvèja suvalgius riebaus maisto [3]. Ūminio cholecistito diagnostika remiasi vietiniais ar sisteminiais uždegimo požymiais ir vaizdo tyrimais. Nors yra nesutarimų dẻl optimalių kriterijų, kuriais remiantis nustatoma klinikinè diagnozé, patikimiausi diagnostiniai kriterijai pateikiami Tokijo gairèse.

Tyrimo tikslas - išanalizuoti bei aptarti įrodymais pagrịstą informaciją apie ūminio kalkulinio cholecistito etiologiją, rizikos veiksnius, klinikinius simptomus bei diagnostiką.

\section{Tyrimo medžiaga ir metodai}

Taikyta sisteminè mokslinès literatūros bei dokumentų apžvalga ir analizè. Duomenų buvo ieškoma Google Scholar, UpToDate, Cochrane bei Medline (PubMed) duomenų bazèse. Visateksčiai straipsniai atrinkti, jei jų pavadinimas, santrauka ar reikšminiai žodžiai nurodè, kad tyrimas tinkamas įtraukti į šią apžvalgą. Pasirinktos tik anglų kalba skelbtos publikacijos. Vartoti nurodyti raktažodžiai. Atrinkti, išanalizuoti ir apibendrinti 6 viso teksto straipsniai.

\section{Tyrimo rezultatai}

Etiologija ir rizikos veiksniai. Apžvelgiant naujausią literatūrą, išsiskiria priežastys, sukeliančios ūminị kalkulinị ir nekalkulinị cholecistitą. Pabrèžiama, kad ūminị kalkulinị cholecistitą dažniausiai sukelia tulžies akmenys, užkimšę latakus bei tulžies pūslès sienelių išemija dèl kraujotakos sutrikimų. Nẻra galutinai aiški patogeninių mikroorganizmų reikšmé ūminio kalkulinio cholecistito atsiradimui. Teigia- 
mos mikoorganizmų kultūros iš tulžies išauginamos tik 50-75 proc. atvejų [1]. Retais atvejais ūminis tulžies pūslès uždegimas pasitaiko nesant akmenu - tai vadinamasis nekalkulinis cholecistitas. Literatūroje minima, kad badavimas, visiškas parenterinis maitinimas, narkotiniai analgetikai ir nejudrumas yra ūminį nekalkulinị cholecistitą predisponuojantys veiksniai. Aprašomi reti atvejai, kai ūminis nekalkulinis cholecistitas pasireiškia kaip atipinis klinikinis požymis ūmios Epstein-Barr virusinès infekcijos metu [4]. Minimi ir rizikos veiksniai, dèl kurių didejja tulžies pūslès akmenligès paplitimas: nutukimas, cukrinis diabetas, metabolinis sindromas, dislipidemija, kepenų cirozè ir lètinè $\mathrm{C}$ hepatito infekcija [5].

Simptomai. Ir kalkuliniam, ir nekalkuliniam cholecistitui būdingas pykinimas, vẻmimas ir skausmas po dešiniuoju šonkaulių lanku. Skausmas dažniausiai suintensyvejja suvalgius riebaus maisto [3]. Fizinio ištyrimo metu ligoniai paprastai karščiuoja $\left(37,5-38,5^{\circ} \mathrm{C}\right)$, palpuojant pilvą juntamas skausmingumas ir pilvo sienos raumenu itempimas dešiniojoje hipochondrinejje srityje, dažnai nustatomas Merfio simptomas. Merfio simptomo jautrumas ir specifiškumas atitinkamai yra 20,5 ir 87,5 procento [6].

Diagnostika. Ūminio cholecistito diagnostika remiasi vietiniais ir (ar) sisteminiais uždegimo požymiais ir vaizdo tyrimais. Pacientas dažniausiai atvyksta dèl pilvo skausmo po dešiniuoju šonkaulių lanku. Objektyvaus tyrimo metu tulžies pūslès projekcijoje nustatomas skausmingumas, kuris sustipreja perkutuojant ar palpuojant, Merfio simptomas dažniausiai būna teigiamas, pacientui nustatoma padidejusi kūno temperatūra. Atlikus laboratorinius tyrimus, randama leukocitozè, padidèjęs $\mathrm{C}$ reaktyvaus baltymo kiekis, daliai ligonių padidejja kepenų fermentų ir bilirubino koncentracija kraujo serume. Pirmo pasirinkimo instrumentinis tyrimas pilvo organų echoskopija, jautrumas 81 proc., specifiškumas 83 procentai [6]. Echoskopuojant dažniausiai matoma sustorèjusi tulžies pūslès sienelè ( $>4 \mathrm{~mm})$, padidèjusi tulžies pūslè $(>8 \mathrm{~cm},>4 \mathrm{~cm})$, randami ịstrigę tulžies pūslès akmenys. Pilvo echoskopijos metu nenustačius ūminiam cholecistitui būdingų požymių, ar jais abejojant, gali būti atlikti papildomi vaizdo tyrimai: pilvo KT ar MRT. Nors yra nesutarimų dèl optimalių kriterijų, kuriais remiantis nustatoma klinikinè diagnozè, patikimiausi diagnostiniai kriterijai pateikiami Tokijo gairèse.

\section{Išvados}

1. Dažniausiai ūminị cholecistitą sukelia akmens ịstrigimas tulžies latakuose.

2. Būdingi simptomai: pykinimas, vėmimas, skausmas po dešiniuoju šonkaulių lanku.

3. Lietuvoje, kaip ir kitose išsivysčiusiose šalyse, ūminio cholecistito diagnostika remiasi Tokijo gairemis.

\section{Literatūra}

1. Fialkowski E, Halpin V, Whinney RR. Acute cholecystitis. BMJ Clin Evid 2008;2008:0411.

2. Kim KH, Kim JS, Nam S-H, Kim KU, Kim W, Kim YH. Acute acalculous cholecystitis after laparoscopic appendectomy in a young healthy patient: report of a case. Korean J Hepatobiliary Pancreat Surg 2013;17(2):83-5.

https://doi.org/10.14701/kjhbps.2013.17.2.83

3. Bridges F, Gibbs J, Melamed J, Cussatti E, White S. Clinically diagnosed cholecystitis: a case series. J Surg Case Rep 2018;2018(2).

https://doi.org/10.1093/jscr/rjy031

4. Branco L, Vieira M, Couto C, Coelho MD, Laranjeira C. Acute Acalculous Cholecystitis by Epstein-Barr Virus Infection: A Rare Association. Infect Dis Rep 2015;7(4).

https://doi.org/10.4081/idr.2015.6184

5. Stinton LM, Shaffer EA. Epidemiology of Gallbladder Disease: Cholelithiasis and Cancer. Gut Liver 2012;6(2):172-87.

https://doi.org/10.5009/gnl.2012.6.2.172

6. Yokoe M, Hata J, Takada T, Strasberg SM, Asbun HJ, Wakabayashi G, et al. Tokyo Guidelines 2018: diagnostic criteria and severity grading of acute cholecystitis (with videos). Journal of Hepato-Biliary-Pancreatic Sciences 2018;25(1):41-54.

https://doi.org/10.1002/jhbp.515

\section{ACUTE CALCULOUS CHOLECISTITIS: ETIOLOGY, RISK FACTORS, CLINICAL SYMPTOMS AND DIAGNOSIS \\ M. Balčytis}

Keywords: cholecystitis, acute cholecystitis, calculous cholecystitis, callbladder disease, Tokyo guidelines.

Summary

Gallstones are found in up to $95 \%$ of patients with acute cholecystitis. One of the most common complications of gallstones is acute inflammation of the gallbladder. In Lithuania, 7,000 cholecystectomies are performed per year, which is the third most frequent operation in Lithuania. Women get this disease more often, especially before the age of 50. Patients most often complain of pain under the right rib cage, nausea, vomiting. The diagnosis of acute cholecystitis is based on the criteria set out in the Tokyo Guidelines. The aim of this study was to evaluate, systematize and analyze the data presented in the scientific literature on acute calculous cholecystitis, etiology, significant risk factors that may affect the development of this pathology, clinical symptoms of the disease and diagnostic features.

Conclusions. 1. Acute cholecystitis is most commonly caused by gallstone entrapment in the bile ducts. 2 . The most common symptoms of the disease are nausea, vomiting and pain under the right rib cage. 3. In Lithuania, as in other developed countries, the diagnosis of acute cholecystitis is based on the Tokyo guidelines.

Correspondence to: mantas.balcyt@gmail.com

Gauta 2021-05-25 